The Review of Finance and Banking

print ISSN 2067-2713, online ISSN 2067-3825

Volume 12, Issue 1, Year 2020

http://dx.doi.org/10.24818/rfb.20.12.01.02, Pages 19-30

\title{
DETERMINANTS OF VENTURE CAPITAL INVESTMENT IN INDIA: A TIME SERIES ANALYSIS
}

\author{
MOHAMMAD MUSTAFA AND SYED SHAHID MAZHAR
}

\begin{abstract}
The purpose of this study is to explore how venture capital investment is sensitive to the macro-economic variables in emerging market economies like India. We examine the determinants of venture capital investment considering domestic factors such as GDP growth, inflation rate, and stock market liquidity. From a global perspective, we have considered global liquidity as an influential factor. Based on quarterly data spanning between Q1, FY2007, and Q4 FY2017, the vector error correction method explores that global liquidity is a crucial factor along with the domestic macroeconomic variables. We believe that while the robust economic outlook is critical for attracting venture capital investment, global liquidity acts as a catalyst for the supply of such investment.
\end{abstract}

\section{Introduction}

From a theoretical perspective, venture capital provides financial assistance to the entities at an early stage for establishing their business in the market. Therefore, this capital can be broadly defined as equity funding dedicated to early-stage or startup ventures having the potentiality to register faster growth or even become a unicorn.

While arguing how venture capital investment is indispensable to an economy, Kortum and Lerner (2000) state that venture capital investment is more powerful than corporate Research and Development $(\mathrm{R} \& \mathrm{D})$ to trigger a wave for innovation activities. In addition, it also promotes an entrepreneurial culture in an economy. Therefore, venture capital investment has emerged as one of the most lucrative corporate financing sources in the emerging market space that includes India. Consequently, venture capital investment has been drawing policy-makers and 'researchers' attention in many countries, over the last many years.

In terms of the quantum, India has attracted net venture capital investments of $\$ 650$ million billion in Q1, FY08 but this money has remained volatile over the years (FY08 and FY17). However, earlier literature reveals that GDP growth is not the only factor that determines the venture capital investment. Given this background, venture capital investments have reacted differently to prevailing market conditions, and domestic variables 'don't seem to explain everything.

Received by the editors November 14, 2019. Accepted by the editors May 8, 2020.

Keywords: Venture capital, Financial Market, Macroeconomic, Monetary Policy.

JEL Classification: G24, E44, E5.

Mohammad Mustafa, PhD Candidate, Chairman \& Managing Director, Small Industries Development Bank of India, New Delhi, India. E-mail: md.mustafa.research@outlook.com.

Syed Shahid Mazhar, PhD, Associate Professor and Head, Department of Commerce \& Business Management Integral University, Lucknow, India. E-mail: shahid.dphil@gmail.com.

This paper is in final form and no version of it will be submitted for publication elsewhere. 


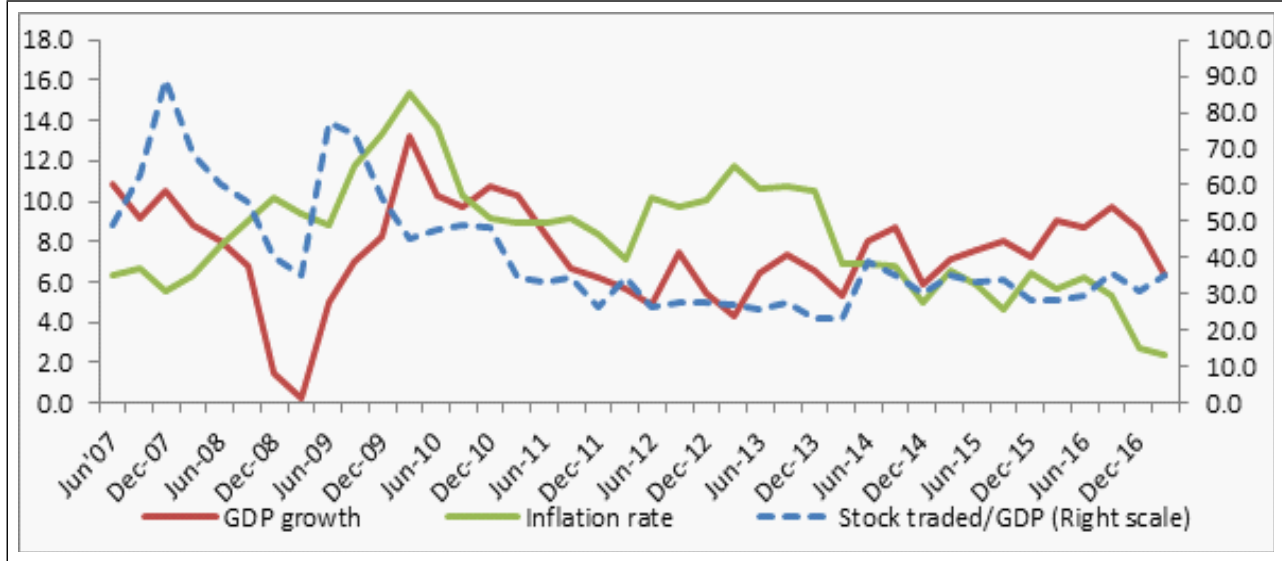

Fig 1: Trend of GDP growth, Inflation rate and Stock traded to GDP ratio (Source: Author's calculation, RBI, NSE)

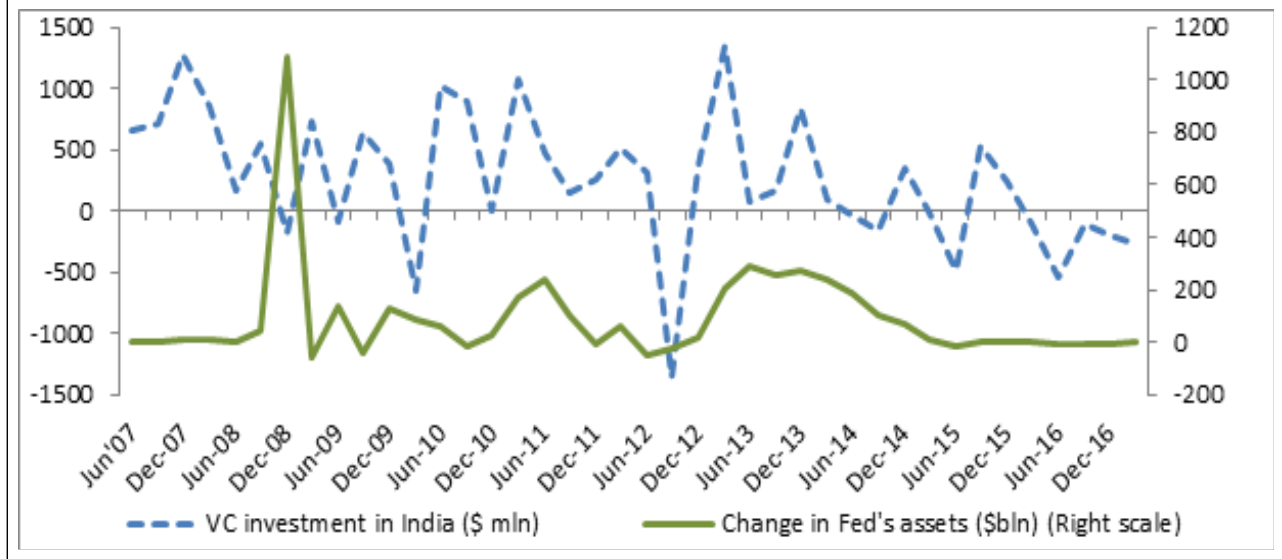

Fig 2: Trend of net venture capital investment in India and change in Federal Reserve's total assets (Source: Author's calculation, SEBI, Federal Reserve Bank of St. Louis)

\section{The Global Liquidity Question}

While, there are several studies on global liquidity and FDI - assessments pertaining to venture capital investment, a form of FDI, is limited to domestic factors only. We note that over an eleven-year period, approximately $63 \%$ of venture capital funding originated from abroad, with the domestic sources taking over the remaining share. Therefore, global factors are indeed playing an important role in venture capital flows into the country.

After the global financial crisis in 2008, the central banks of advanced economies (A.E.s) adopted an unconventional monetary policy (UMP) to stimulate economic growth as well as to reinvigorate their asset markets (Smaghi, 2009 and Acharya, Salvi \& Kumar, 2017). Accordingly, as major central bank balance sheets expanded, excess liquidity was unleashed into the global system. As a result, the yield chasing capital from the A.E.s flooded the emerging markets such as India, which were offering relatively better returns while being structurally stable.

This paper, therefore, attempts to explore whether global liquidity, especially pertaining to the accommodative monetary policy adopted by A.E. central banks, influences the flow of venture capital investments in India.

Earlier, several studies including Lim \& Mohapatra (2016) and Acharya, Salvi \& Kumar (2017) used money supply (M2) of major central banks as proxy for global liquidity. Bhattarai, Chatterjee and Park (2018), on the other hand used an approach in which net asset purchased 
(by a central bank) was used as a proxy for liquidity. In this study, we used the latter approach to meet our objectives and explore whether foreign central bank actions (such as the Quantitative Easing or Reversal of Quantitative Easing of the .S.U.S. Federal Reserve) are determinants of venture capital investment in India.

As we go forward, the rest of the paper is organized in the following format. Section 2 highlights the review of the literature. Section 3 contains analytical framework and data \& methodology for empirical analysis. Finally, Section 4 discusses empirical results and Section 5 provides the conclusion of this study.

\section{Review of Literature}

This section reviews the earlier literature on the determinants of venture capital investments at a macro-economic level. It will give us an insight into how such investments are influenced by the different macro-level factors in an evolving economic environment.

Gomper and Lerner (1998) developed a model to examine whether macroeconomic factors drive the venture capital investment in the United States. The study utilized fixed-effect model for the period of 1969 to 1994 to explore the supply and demand-side factors that drive this investment. The empirical analysis reveals that demand-side factors such as economic growth and interest rate are pivotal in influencing venture capital investment. Consequently, a fastergrowing economy can create more investment opportunities for the entrepreneurs. Therefore, the authors argue that faster economic expansion can be a catalyst for a higher demand for venture capital financing. However, IPO, which is considered as a proxy for stock market liquidity, is found to be insignificant.

Jeng and Wells (2000), on the other hand, tried to explore this by considering countries from different geographical locations. A sample of 21 countries were considered where information on venture capital is available during 1986-95. Alternate to the findings of Gomper and Lerner (1998), they revealed a strong association of IPO and venture capital investment. Further clarifying the argument, Jeng and Wells (2000) stated that IPO is the most attractive exit option for the venture capital investors. Therefore, higher venture capital investment leads to more number exits through IPO and not vice-versa. Hence, they considered growth in market capitalization as a proxy for stock market liquidity instead of IPO. It was however found that market capitalization along with GDP growth has no role in venture capital fund raising. While explaining the nexus between venture capital investment and GDP growth, they argue that government-funded, and non-government funded venture capital can have different sensitivities to the GDP growth. Therefore, the influence of GDP growth is inconclusive.

Schertler (2003) tried to examine the influence of market capitalization in venture capital investment with a homogeneous set of countries; for the purpose, Western European region was considered for the study. In order to follow a unique approach, the authors defined market capitalization ratio to GDP of a country as a degree of stock market liquidity. It was eventually observed that market capitalization has a positive significant influence on the dependent variable. Schertler rejected the approach of Jeng and Wells (2000) and concluded that market capitalization ratio to GDP of a country can be a more appropriate measurement of market liquidity while assessing its influence on venture capital investment. Further, in order to reinforce his findings, he states that liquid stock market can provide opportunity for entrepreneurs to regain control on their own entities. Therefore, entrepreneurs may express interest in venture capital financing - when part of a highly liquid stock market. Impact of stock market liquidity on venture capital investment was further confirmed by Cherif and Gazdar (2011) while examining the European region.

Romain and Potterie (2004) considered sixteen OECD countries to examine whether rate of interest can determine the intensity of venture capital investment. This is because fund providers may expect higher (lower) returns if the rate of interest increases (decreases). Therefore, the concerned authors considered rate of interest as an important explanatory variable, which was ignored by earlier studies. A panel regression technique explored that interest rate 
and GDP growth are the strong determinants of venture capital intensity in the OECD countries. Furthermore, it was observed that the nature of venture capital investment is procyclical - it responds positively to the GDP growth.

Felix, Gulamhussen, and Pires (2007) analyzed the determinants of venture capital in a similar approach to the study of Jeng and Wells (2000). A panel regression was considered for a period between 1992 and 2003 for 23 European countries. The findings reveal that two macro-variables, IPO and market capitalization, associated with the stock market are found to be strong determinants of venture capital investment. The authors endorse the earlier work of Schertler (2003) and state that active stock market is pivotal for attracting more venture capital investment. Nevertheless, rate of interest is also found to be positive and significant. Therefore, the concerned authors believe that at a lower rate of interest, the demand side may overwhelm the supply side of venture capital. In case of GDP growth, the result is in line with the findings of Gomper and Lerner (1998), Romain and Potterie (2004).

Taking further the research, Marti and Balboa (2001) examined how this industry (Venture Capital) work in countries where availability of information related to the return of such investment is limited. A panel regression model reveals that macro-variables are weak determinants of venture capital funds under asymmetric information exist. Under such scenario, they state that fundraising capability of the fund managers can play a crucial role.

The government is also a major fund provider to venture capital investment. The intension of government funding to the venture capital investment may differ from the private players. Therefore, looking purely from a supply-side viewpoint, Manigert and Beuselinck (2001) tried to explore the factors determining the supply of venture capital by governments in the European region. For an empirical analysis, the study includes a time series data from 1989 to 1999. A panel regression technique explored a negative association between GDP growth and venture capital investment. While justifying the finding of inconsistency with the earlier literature, the authors argue that governments might be using this fund as a tool to stimulate growth. Governments supply more funds to curb any downward trend in the economic outlook. This, in turn, establishes an inverse relationship between venture capital investment and GDP growth.

Bonini and Alkan (2011) tried to explore how macro-economic stability is crucial for venture capital investment decision. They used inflation rate and interest rate as proxy for macroeconomic stability. Using panel regression for 16 countries, the authors explored that inflation rate, which is included in the model for the first time, is an influential factor in venture capital investment. Furthermore, other macro-variables such as GDP growth, interest rate, and stock market liquidity are also found to be influential factors. However, influence of GDP growth at an early stage of investment only. This implies that investors mostly assess the economic outlook of a country at an initial stage of investment and not later.

In a unique approach, Groh and Liechtenstein (2012) has developed an index with 51 parameters to measure the attractiveness of an economy for venture capital investment. The study ranked the 116 countries (including 83 emerging markets) based on the selected parameters. The index ranks China as leading emerging markets for venture capital investment followed by Malaysia, South Africa, Chile, Saudi Arabia, Poland, and India. Based on index approach, the authors explored that an economy with size and catch-up potential always remains in the limelight of the venture capital investment. GDP and GDP growth reflects the size of an economy and catch-up potential, respectively. Therefore, it can be concluded that GDP growth can be a potential explanatory variable for the venture capital investment as well.

Ning, Wang and $\mathrm{Yu}$ (2015) tried to explore the importance of macroeconomic factors on venture capital investment in the U.S. Using high frequency data (quarterly observations), it was concluded that venture capital investment has a long-run association with GDP growth. A long-run causality between venture capital investment and GDP growth was further explored with an Engle-Granger test. In addition to GDP growth, number of IPOs and inflation rate are also found to be positive and significant. However, the value with less than $20 \%$ shows a poor specification of the model. 
In order to have a more comprehensive study, Groh and Wallmeroth (2016) considered 118 emerging market economies including India. The authors argue that venture capital investment in emerging market depends on a 'country's stage/level of development. The study considered a different set of variables such as corruption index, M\&A, export to GDP ratio, legal rights index, corporate tax, .P.I.P. protection, innovation for a panel regression. This model measures the venture capital investment by quality of governances and socio-economic condition in the considered economies. It is however observed that certain major macroeconomics variables such as GDP growth, inflation rate and interest rate that reflect the real outlook of an economy have been ignored in this study. Consequently, the combinations of new variables could explain just around $16 \%$ of variation in the dependent variable.

In another study, Pradhan, Arvin, Nair, Bennett and Bahmani (2018) tried to explore the interrelationship between venture capital, economic growth and digital economy in the European region. The study included 25 European countries for the period of 1989 to 2016 and utilized vector error correction model. It was observed that GDP growth can help the venture capital investment to converge to long-run equilibrium, which is in line with the findings of Ning, Wang and $\mathrm{Yu}(2015)$.

Ndlwana and Botha (2018) tried to explore the determinants of private equity investment in BRICS countries (Brazil, Russia, India, China, and South Africa). Their panel regression endorse the earlier study of Felix, Gulamhussen, and Pires (2007) that domestic factors such as growth in market capitalization, GDP growth and interest rate are the strong determinants of this alternative investment.

\section{Findings in Indian Context}

In a country-specific study, Neerza and Tripathi (2019) tried to explore influential factor for the alternative investment category in India by taking private equity investment. This study segregated the parameters into country-specific and firm-specific determinants for a firm-level analysis. However, this study is inconclusive while measuring impact of country-specific factors on the alternative investment funds. It was observed that impact of macro variables varies sector-wise.

The literature has experimented with the determinants of venture capital investment by considering only domestic factors. Acharya, Salvi, \& Kumar (2017) tried to explore how capital flow in Emerging Market Economies (EMEs) is affected by external factors along with domestic factors. Therefore, this study considered interest rate differential and global liquidity. The OLS result shows that capital inflows are positively influenced by global liquidity. However, degree of influence varies based on the nature of capital. The authors considered money supply (M2) of major central banks (Fed, ECB, BoJ and BoE) as proxy for global liquidity.

It is apparent from the past studies that GDP growth, macro-economic stability, and vibrant capital market liquidity are the potential explanatory variables for the venture capital investment. These factors however represent the domestic influence on venture capital investment. From a supply-side perspective, external factors such as global liquidity and interest rate differential can also be a strong determinant of the venture capital investment. This is because, yield chasing capital can come to emerging markets when global liquidity is at its peak. Moreover, in case of emerging market economies, it is noted that capital inflows are highly determined by the monetary policy of the advanced economies. Therefore, inducing some external factors that highly influence the flow of investment - can strengthen the model specification. Moreover, in order to understand the venture capital investment behavior in India, a single country analysis would provide more meaningful information. This understanding is based on the assertion of Fisher and Smyth (2013), who argue that .S.U.S. private equity investors focus on market-specific problems when investing in emerging markets. 


\section{Analytical Framework and Empirical Estimation}

For understanding the role of macroeconomic factors on venture capital investment, we have followed the approach adopted by Bonin \& Alkan (2011). So far, earlier literature has considered only domestic factors as determinants of venture capital investment. However, the external financial environment can also influence the venture capital investment through the supply side, especially in EMEs. Therefore, we considered global liquidity and interest rate differential as an additional explanatory variable in our model. When considering empirical analysis, earlier studies have employed OLS or panel regression techniques. However, Pradhan et al. (2018) examined the influence of macro-variable with a VAR based model. The literature argues that venture capital investment can be influenced by the past behavior of macroeconomic conditions. Moreover, it was argued that in the venture capital market, fresh investment is influenced by the past performance of a field (Eg. Marti and Balboa, 2001). This indicates that the dependent variable is influenced by its own lagged values as well. Considering this, Pradhan et al. (2018) have considered a VAR based approach. Therefore, we have taken the empirical framework from the work of Pradhan (2018) and employed a vector error correction model (VECM), while also considering unit root tests and co-integration test. The VECM model can be expressed, as presented in Equation (1).

$$
\begin{array}{r}
D V C_{t}=\alpha_{0}+\beta_{1} \text { DGrowt } \\
+\beta_{4-1}+\beta_{2} D S T_{t-1}+\beta_{3} D C P I_{t-1}+\beta_{5} D D I_{t-1}-\beta_{6} E C T_{t-1}+u_{t}
\end{array}
$$

Where $t$ denotes the time-series dimension of quarterly data. Similarly, D is the first difference of the variables. .C.V.C. is venture capital investment. Growth is GDP growth, .T.S.T. is stock market liquidity, Inflation is growth in consumer price, .L.G.L. is global liquidity, ECT is error correction term, $\alpha_{0}$ is the constant variable, and $u_{t}$ is residual.

\subsection{Independent variables.}

5.1.1. Domestic Factors. GDP growth (Growth): The first macro variable in this study is real GDP growth (year on year) based on the data provided by CSO. As India is a fastexpanding economy, faster GDP growth should create more investment opportunities for venture capital investors. Therefore, we expect this variable to have a positive impact on the dependent variable. In literature, Gomper and Lerner (1998), Romain and Potterie (2004), and Ndlwana and Botha (2018) have proven a positive impact of this variable on the dependent variable.

Stock Traded (S.T.): In the case of the stock market, some studies have considered number IPO or market capitalization scaled by GDP as a proxy for stock market liquidity. However, in the case of nexus between venture capital investment and IPO, the number of IPO is a result of venture capital investment, as argued by Bonini \& Alkan (2011). They further argue that market capitalization is a part of an IPO. Therefore, the stock traded scaled by GDP can be a true measure of stock market liquidity. We expect this variable to have a positive impact on the dependent variable. Inflation rate (CPI): The inflation rate reflects the consumer demand in an economy. Moreover, this also indicates the macro-economic stability in a country. At a higher consumer demand, the inflation rate will be high as well. Hence, investors's commitment to the fund manager will be higher when the rate of inflation is high. Therefore, we expect the coefficient of this variable to have a positive sign. In an earlier study, Bonini \& Alkan (2011) have proven this variable as a driving factor of venture capital investment.

5.1.2. External Factor. Global Liquidity (G.L.): During the time of higher global liquidity, the yield chasing capital flow into EMEs. Therefore, we expect this variable to have a positive influence on venture capital investment in an emerging market like India.

Interest rate differential (DI): We find that interest rate differential between A.E.s and EMEs is also a significant factor in determining such investment flows. We believe that interest rate differential is more appropriate than taking domestic interest rate, on a standalone basis. 
This variable was considered by Ahmed \& Zlate (2013) and Acharya, Salvi, Kumar (2017) for examining the determinants of capital inflows.

\section{Data and measurement of variables}

For the empirical analysis, this study has considered quarterly data from June, 2007 to March 2017 (40 observations for each variable) in India. The time period and frequency of data are considered as per the availability of data on venture capital. This study uses five macroeconomic variables such as net venture capital investment, real GDP growth, stock market liquidity, inflation rate, and change in Federal ' 'Reserve's balance sheet on the asset side. Data on GDP, inflation rate, and 10-year Indian sovereign yield are collected from the database of Database on Indian Economy (DBIE), Reserve Bank of India. Data on volume of stock traded is obtained from database of National Stock Exchange of India (NSE). Data on venture capital investment has been collected from the Securities and Exchange Board of India (SEBI). Similarly, Federal ' 'Reserve's balance sheet and 10-year U.S. sovereign yield have been collected from the Federal Reserve Bank of St. Louis.

The dependent variable V.C. is measured as the ratio of net venture capital investment to nominal GDP. GDP growth is annual percentage change in gross domestic production of India. Stock, proxy for stock market liquidity, has been measured as volume of stock traded to nominal GDP ratio. Inflation rate is year on year change in consumer price index for industrial workers. Global liquidity (G.L.) is measured as a change in the asset side of the log balance sheet of the Federal Reserve. Interest rate differential (DI) is measured as a difference between the 10-year sovereign yield of India and the United States.

\begin{tabular}{|l|l|c|c|}
\hline \multicolumn{2}{|c|}{ Table 1 - Description of variables } & Notation & Predicted sign \\
\hline Variables & \multicolumn{1}{|c|}{ Description } & VC & Dependent variable \\
\hline Venture capital investment & Net venture capital investment scaled by nominal GDP & + \\
\hline GDP Growth & Annual percentage growth in inflation-adjusted to GDP & GDP growth & ST \\
\hline Stock Traded & The stock traded scaled by nominal GDP & CPI & + \\
\hline Inflation rate & Growth in the consumer price index & G.L. & + \\
\hline Global Liquidity & Change in the asset side of the Fed's balance sheet & DI & + \\
\hline Interest rate Differential & Difference bet. 10-year Indian and .S.U.S. sovereign yield & & + \\
\hline
\end{tabular}

\section{Empirical Results}

7.1. Descriptive Statistics. The descriptive statistics of the selected macroeconomic variables are presented in Table A1. The minimum and maximum values for all the variables are not far away from the mean value. This indicates that no outliers are present in the data set. The summary statistics presented in Table A1. Standard deviation gives an overview of the historical behavior of the variables. For example, a variable such as venture capital, market capitalization, and .L.G.L. seems to be highly volatile.

7.2. Unit Root Test. In order to test whether the time-series variables have stationarity trend or not, the unit root test has been conducted as presented in Table 2. We have used (augmented) Dickey-Fuller (ADF) statistics and Dickey-Fuller Generalized Least Square (DFGLS) as suggested by Dua and Ranjan (2010) and Kim and Choi (2017). The unit root test result shows that the null hypothesis of non-stationarity nature of the variables in the model can be rejected. Table 2 shows that except the variable DI, all the variables are found to be stationarity. The coefficient of all the variables is found to be negative. A higher negative value of the coefficients indicates that the hypothesis of non-stationarity behavior of the macrovariables is strongly rejected. 


\begin{tabular}{|l|c|c|}
\hline \multicolumn{3}{|c|}{ Table 2 - Result of Unit Root Test } \\
\hline & ADF & DF-GLS \\
\hline VC & $-4.03^{* * *}$ & $-3.16^{* * *}$ \\
\hline Growth & $-3.12^{* *}$ & $-2.56^{* *}$ \\
\hline Stock & $-2.66^{*}$ & $-3.03^{* * *}$ \\
\hline GL & $-4.74^{* * *}$ & $-4.59^{* * *}$ \\
\hline Inflation rate & $-1.43^{*}$ & 1.34 \\
\hline DI & -2.03 & -1.46 \\
\hline Note: the values presented in the table are coefficient of unit root tests. \\
\hline \multicolumn{3}{|c|}{$* * *$ indicates significant at 1\% level } \\
\hline \multicolumn{3}{|c|}{$* *$ indicates significant at $5 \%$ level } \\
\hline \multicolumn{3}{|c|}{$*$ indicates significant at 10\% level } \\
\hline
\end{tabular}

7.3. Co-integration Tests. Further, after verifying that all variables are integrated at first order I (1), we can proceed for exploring a long-run dynamic among the selected macro-variables. Therefore, in next step, we performed a co-integration test to explore whether a long-run relationship exists between V.C. and macroeconomic variables of GDP growth, stock market liquidity, global liquidity, and inflation rate; in this regard 'Johansen's co-integration test has been conducted. As interest rate differential does not follows stationarity, we excluded it from our model. Before running the 'Johansen's co-integration test, VECM lag-length was selected as presented in Table A2. All the alternative tests clearly suggest one lag. The co-integration with one lag suggests at least one co-integration equation at five percent level among the selected macroeconomic variables (Table 2).

\begin{tabular}{|c|c|c|c|c|}
\hline \multicolumn{5}{|c|}{ Table 3 - 'Johansen's co-integration test } \\
\hline R & L.L. & Eigenvalue & Trace & Critical value (5\%) \\
\hline 0 & 473.07 & & 94.89 & 76.07 \\
\hline 1 & 495.12 & 0.677 & $50.78^{*}$ & 53.12 \\
\hline 2 & 510.27 & 0.54 & 20.49 & 34.91 \\
\hline 3 & 516.07 & 0.257 & 8.89 & 19.96 \\
\hline 4 & 519.14 & 0.146 & 2.75 & 9.42 \\
\hline \multicolumn{5}{|c|}{ Note: * indicates significant at 5 percent level } \\
\hline
\end{tabular}

\section{Vector Error Correction Model (VECM)}

8.1. Normalization of Co-integration of Coefficient. In the long-run equation, venture capital investment is positively influenced by GDP growth, stock market liquidity, global liquidity, and inflation rate. The sign of the coefficient of GDP growth, inflation rate is positive, which is in line with earlier work of Bonini and Alkan (2011). A higher coefficient of GDP growth implies that the influence of the economic outlook on venture capital is more robust than the other macro-factors. A positive association with GDP growth was observed by several studies such as Gomper and Lerner (1998), Felix et al. (2007), Ning et al. (2015), Ndlwana, and Botha (2018). Further, our study confirms a long-term association between venture capital investment and GDP growth, which is similar to the earlier work of Pradhan et al. (2018).

In the case of stock market liquidity, we considered stock traded to GDP ratio as a proxy. The variable is found to be positive and significant, which is in line with the finding of Bonini and Alkan (2011). It confirms that stock market liquidity can leads to higher venture capital investment in India. We have included global liquidity as an additional variable in the model. A positive sign and significant at one percent level confirm our hypothesis that venture capital investment increases when global liquidity is high. This makes us conclude that ten percent of increases in global liquidity leads the venture capital investment by four bps. It can be further stated that higher global liquidity can be a catalyst for a higher supply of venture capital 
investment funding from limited partners. Therefore, global factors are also equally important as compared to the country-specific factors.

\begin{tabular}{|c|c|c|c|c|c|}
\hline \multicolumn{5}{|c|}{ Table 4 - Normalization of Co-integration of Coefficient } \\
\hline & GDP & GL & ST & CPI & Constant \\
\hline Coefficient & 0.0135 & 0.0039 & 0.0018 & 0.0079 & 0.0021 \\
\hline p-value & $0.005^{* * *}$ & $0.001^{* * *}$ & $0.001^{* * *}$ & $0.011^{* *}$ & $0.000^{* * *}$ \\
\hline \multicolumn{6}{|c|}{ Note: ${ }^{* *}$ indicates significant at one percent level, } \\
\hline \\
${ }^{* *}$ indicates significant at five percent level; \\
\hline \multicolumn{6}{|c|}{ The sign of the variables is changed after normalization of the equation. } \\
\hline
\end{tabular}

8.2. Short-Run Error Correction Model. A stable long-run relationship among the selected variables paves the way for estimation of error correction model to explore both the short-run and long-run behavior of the variables in the model. The coefficient in Table-5 represents the short-run elasticity. The coefficient of E.C. term shows the speed of adjustment to the long-run equilibrium. A negative sign of the ECM (-1) is meaningful (Fernando, 2018) as it implies that the endogenous variable (V.C. here) is returning to its equilibrium path after a temporary shock. The ECM (-1) coefficient is (-) 1.65, which implies that the speed of adjustment for venture capital investment to its long-run equilibrium is very fast.

\begin{tabular}{|c|c|c|}
\hline Table 5 - Short-Run Error Correction Model \\
\hline & Coefficient & p-value \\
\hline ECT (-1) & -1.6557 & $0.000^{* * *}$ \\
\hline DVC(-1) & 0.4105 & $0.019^{* *}$ \\
\hline DGDP(-1) & -0.018 & $0.098^{*}$ \\
\hline DGL(-1) & -0.0007 & 0.647 \\
\hline DST(-1) & 0.0029 & 0.121 \\
\hline DCPI(-1) & -0.0082 & 0.499 \\
\hline Breusch-Pagan test & 2.8000 & $0.094^{*}$ \\
\hline LM test & 32.4020 & 0.146 \\
\hline Jarque-Bera test & 2.3040 & 0.315 \\
\hline$R^{2}$ & \multicolumn{2}{|c|}{0.658} \\
\hline AIC & -25.109 \\
\hline SBC & \multicolumn{2}{|c|}{-26.601} \\
\hline Note: *** indicates significant at one percent level, \\
\hline ** indicates significant at five percent level, \\
\hline * indicates significant at ten percent level \\
\hline
\end{tabular}

Overall, the $R^{2}$ value of the model is 68 percent, which means 68 percent of the variation in the dependent variable is explained by GDP growth, market liquidity, inflation rate, and global liquidity. We find that the $R^{2}$ value increased after introducing global liquidity. This indicates that the earlier studies had lower $R^{2}$ because this variable was excluded from the model. In an unbiased consistent regression model, the residual should be in constant variance, not serially correlated, and normally distributed (Fernado, 2018). Therefore, for validating the model, we have conducted Lagrange Multiplier (L.M.) test for serial correlation, Breusch-Pagan test for heteroscedasticity and normality test with the Jarque-Bera test. Results of these tests have been presented in table-5. All the three tests do not reject the null hypothesis of serial correlation and normal distribution at five percent level.

\section{Conclusion}

Earlier literature widely acknowledged that venture capital investment is highly sensitive to the domestic macroeconomic factors such as GDP growth, vibrant stock market, and macroeconomic stability in an economy. However, we believe that given the current global conditions, 
domestic factors are not the only explanatory variables. Consequently, this study tried to explore whether venture capital investment in an emerging economy like India - is sensitive to global factors as well.

From the domestic point of view, the study confirms that domestic factors such as stock market liquidity and inflation rate along with GDP growth are influential factors of venture capital investment in India. It is known that under robust domestic economic outlook, investors can expect higher returns. Hence, this stimulates both supply and demand of the venture capital investments.

In addition, during higher global liquidity, supply of venture capital investment can be higher - a function of relative returns. Our research therefore contributes to the existing literature by exploring influence of global liquidity on venture capital investment. This is a major inference for a fund manager as well as to the entities at early stages, which are exploring venture financing. The appropriate time for fundraising for an entity to raise funds would therefore be during a timeframe when global liquidity is high. The condition must nevertheless coexist along with a lucrative domestic macroeconomic outlook.

This study also has its limitations. Venture capital investment can also change with the change in industry dynamic, which this study has not incorporated. Moreover, we have considered only India for our research, which is a single emerging market economy approach. The impact of global liquidity can be tested by considering a group of homogeneous EMEs, if they also have a similar response. Another limitation is that we have considered quarterly observations (40 quarters) spanning from Q1 FY2007 to Q4 FY2017. Due to limited number of observations, we could not include more number of control variables (such as government policy, changing industry dynamic, labor market). A further study incorporating all these variables will enrich the findings and make them more relevant for industry actors.

\section{REFERENCES}

[1] Acharya, A., Salvi, P., \& Kumar S. (2017). Global Liquidity and Foreign Flows to India: An Empirical Assessment, (RBI Occasional Papers $38-1 \& 2$ ), Reserve Bank of India. Retrieved at https://m.rbi.org.in/Scripts/bs_viewcontent.aspx?Id=3519.

[2] Ahmed, S., \& Zlate, A. (2013). Capital Flows to Emerging Market Economies: A Brave New World (International Finance Discussion Papers, No. 1081, June), Board of Governors of the Federal Reserve System. Retrieved from https://www.federalreserve.gov/pubs/ifdp/2013/1081/ifdp1081.pdf.

[3] Bhattarai, S., Chatterjee, A. \& Park, W. Y., (2018). Effects of .S.U.S. Quantitative Easing on Emerging Market Economies (ADBI Working Paper 803). Retrieved at http://dx.doi.org/10.2139/ssrn.3140100.

[4] Black, B. S., \& Gilson, R. J. (1997). Venture capital and the structure of capital markets banks versus stock markets, Journal of Financial Economics, 47(3), 243-277. doi.org/10.1016/S0304-405X(??)00045-7.

[5] Bonini, S., \& Alkan A. S. (2011). The Political and Legal Determinants of Venture Capital Investments around the World, Retrieved from https://ssrn.com/abstract $=945312$.

[6] Cherif, M., \& Gazdar, K. (2011). What drives venture capital investments in Europe? New results from a panel data analysis. Journal of Applied Business and Economics, 12(3), 122-139.

[7] Dua, P. \& Ranlan, R. (2010). Exchange rate policy and modeling in India, (RBI Working Paper 33), Reserve Bank of India. Retrieved from https://m.rbi.org.in/scripts/PublicationsView.aspx?id=12252.

[8] Fernando, A. (2018). Macroeconomic Impact on Stock Market Returns and Volatility: Evidence from Sri Lanka. Business and Economic Journal, 9(4), doi:10.4172/2151-6219.1000379.

[9] Fisher, K. \& Smyth, S. (2013). U.S. Private Equity Investment in Emerging Economies. Journal of International Business and Law, 12(1), 223-257.

[10] Fleix, E.G.S., Gulamhussen, M.A., \& Pires C.P., (2007). The determinants of venture capital in Europe - Evidence across countries. (CEFAGE-UE Working Paper 2007/01). Retrieved from Centre for Advance Studies in Management and economics website: http://www.cefage.uevora.pt/en/producao_cientifica/working_papers_serie_cefage/ the_determinants_of_venture_capital_in_europe_evidence_across_countries.

[11] Gompers, P., Lerner, J., Blair, M., \& Hellmann, T. (1998). What Drives Venture Capital Fundraising? Brookings Papers on Economic Activity. Microeconomics, 1998, 149-204. doi:10.2307/2534802.

[12] Groh, A. P., \& Liechtenstein, H., (2012). Assessing Country Attractiveness in the Venture Capital and Private Equity Landscape in Emerging Markets, DOI: doi.org/10.2139/ssrn.2021987.

[13] Groh, A. P., \& Wallmeroth, J. (2016), Determinants of venture capital investments in emerging markets, Emerging Market Review, 29, 104-132. DOI: https://doi.org/10.1016/j.ememar.2016.08.020. 
[14] Jeng, L. A., and Wells, P. C., (2000). The determinants of venture capital funding: evidence across countries, Journal of Corporate Finance, 6(3), 214-289. doi.org/10.1016/S0929-1199(??)00003-1.

[15] Kim, J. H., \& Choi I. (2017). Unit root in economic and financial time series: A re-evaluation at the decision-based significant levels, Econometrics, 5(41), 1-23. doi.org/10.3390/econometrics5030041.

[16] Kortum, S., and Lerner, J. (2000). Assessing the contribution of venture capital to innovation, The Rand Journal of Economics, 31(4), 674-692. .

[17] Lim, J. J., and Mohapatra S. (2016). Quantitative Easing and the Post-crisis Surge in Financial Flows to Developing Countries, Journal of International Money and Finance, 68, 331-357. DOI: doi.org/10.1016/j.jimonfin.2016.02.009.

[18] Manigart, S., \& Beuselinck, C. (2001). Supply of venture capital by European government, (Faculteit Economie, University Gent Working Paper No. 2001/111). Retrieved from http://citeseerx.ist.psu.edu/viewdoc/download?doi=10.1.1.199.5020\&rep=rep1\&type=pdf.

[19] Marti, J., \& Balboa, M. (2001). Determinants of private equity fundraising in western Europe. (EFMA Working Papers). DOI: doi.org/10.2139/ssrn.269789.

[20] Ndlwana, G., Botha, I. (2018). Determinants of Private Equity Investments across the BRICS Countries. Journal of Private Equity, 21(4), 18-28. Retrieved at www.jstor.org/stable/26497440.

[21] Neerza, N., \& Tripathi, V. (2019). Determinants of private equity investment across sectors in India, Journal of Advances in Management Research, DOI: doi.org/10.1108/JAMR-09-2018-0083.

[22] Ning, Y., Wang, W, Yu, B., (2015). The driving forces of venture capital investments, Small Business Economics, 44, 315-344, DOI: 10.1007/s11187-014-9582-4.

[23] Pradhan, R. P., Arvin, M. B., \& Nair, M., Bennett, S. E., \& Bahmani, S. (2019). Short-term and long-term dynamics of venture capital and economic growth in a digital economy: A study of European countries. Technology in Society, 57(5), 125-134. DOI: https://doi.org/10.1016/j.techsoc.2018.11.002.

[24] Romain, A., \& Potteries, B. V. P. (2003). The determinants of venture capital: A panel data analysis of 16 OECD countries, (IIR Working Paper 03-25), Hitotsubashi University.

[25] Schertler, A. (2003). Driving forces of venture capital investments in Europe: A dynamic panel data analysis (Kiel working paper 1172). Kiel Institute for World Economics. Retrieved from http://hdl.handle.net/10419/17695.

[26] Smaghi, L. B., (2009). Conventional and unconventional monetary policy, Keynote lecture, International Center for Monetary and Banking Studies (ICMB), 28 April 2009. Retrieved at https://www.bis.org/review/r090429e.pdf. 


\section{Appendix}

\begin{tabular}{|c|c|c|c|c|c|}
\hline \multicolumn{7}{|c|}{ Table A1 - Summery Statistics } \\
\hline & Obs & Mean & Std. Dev. & Min & Max \\
\hline VC & 40 & 0.071 & 0.13 & -0.32 & 0.36 \\
\hline Stock & 40 & 40.64 & 16.10 & 23.50 & 88.96 \\
\hline Growth & 40 & 7.47 & 2.45 & 0.20 & 13.26 \\
\hline GL & 40 & 3.96 & 10.7 & -7.79 & 6.14 \\
\hline Inflation rate & 40 & 8.28 & 2.84 & 2.36 & 15.32 \\
\hline DI & 40 & 5.06 & 1.09 & 3.07 & 6.64 \\
\hline
\end{tabular}

Note: Obs is number of observations. .C.V.C. is ratio of venture capital investment to nominal GDP, .T.S.T. is ratio of value of stock traded to nominal GDP, Growth is year on year change in real GDP, Inflation rate is year on year change in consumer price index (industrial workers). .L.G.L. is measured as first difference of ' 'Fed's balance sheet. DI is interest rate differential of 10-year sovereign yields between India and the U.S. The mean of GL 3.96 indicates net increase in the log balance sheet is 3.96 during the period of FY08 to FY17. Similarly, average stock traded is 40.64 percent of GDP during the defined time period. Likewise, average GDP growth, interest rate differential and inflation rate is $7.47,5.06$ and 8.28 percent respectively.

\begin{tabular}{|c|c|c|c|c|c|c|}
\hline \multicolumn{7}{|c|}{ Table A2 - VAR Lag Order Selection Criteria } \\
\hline Lag & LogL & LR & FPE & AIC & HQIC & SPIC \\
\hline 0 & 293.115 & & $4.50 \mathrm{E}-10$ & -15.8397 & -15.7169 & -15.4878 \\
\hline 1 & 307.364 & 28.497 & $2.6 \mathrm{E}-10^{*}$ & $-16.4091^{*}$ & $-16.2249^{*}$ & $-15.8813^{*}$ \\
\hline 2 & 309.587 & 4.4468 & $2.90 \mathrm{E}-10$ & -16.3104 & -16.0648 & -15.6066 \\
\hline 3 & 310.175 & 1.175 & $3.50 \mathrm{E}-10$ & -16.1208 & -15.8138 & -15.2411 \\
\hline 4 & 316.781 & $13.214^{*}$ & $3.10 \mathrm{E}-10$ & -16.2656 & -15.8972 & -13.21 \\
\hline \multicolumn{7}{|c|}{ Note: * indicate significant at five percent level } \\
\hline
\end{tabular}

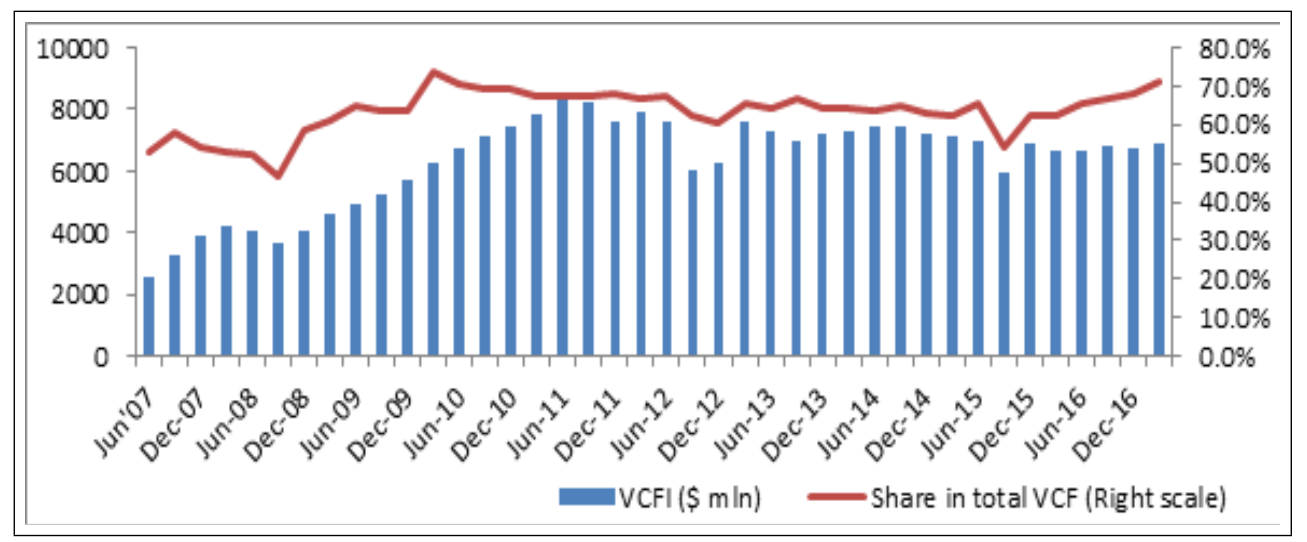

Fig A1: "India's Outstanding Foreign Origin Venture Capital Investment (Source: Author's calculation, SEBI) 